\title{
PERBEDAAN HASIL BELAJAR FISIKA ANTARA MODEL PEMBELAJARAN SAINS TEKNOLOGI MASYARAKAT DAN MODEL PEMBELAJARAN DIRECT INSTRUCTION PADA SISWA KELAS X SMA NEGERI 1 PALU
}

\author{
Lailatul Fikria Rahmawati ${ }^{1}$, Muhammad Ali $^{2}$ dan Yusuf Kendek ${ }^{3}$ \\ Email: laila.phy@gmail.com \\ Program Studi Pendidikan Fisika, Jurusan Pendidikan MIPA, Universitas Tadulako \\ Jl. Soekarno Hatta KM.9 Kampus Bumi Tadulako Tondo Palu - Sulawesi Tengah
}

\begin{abstract}
Abstrak - Penelitian ini bertujuan untuk mengetahui ada tidaknya perbedaan hasil belajar fisika antara model pembelajaran Sains Teknologi Masyarakat dengan model pembelajaran konvensional pada siswa kelas X SMA Negeri 1 Palu. Penelitian ini menggunakan "The non ekuivalen Pretest-posttest design". Pengambilan sampel dilakukan secara purposive sampling. Sampel Pada penelitian adalah kelas X- 6 sebagai kelas eksperimen dan kelas X-8 sebagai kelas kontrol. Instrumen yang digunakan dalam penelitian meliputi perangkat pembelajaran untuk model Sains Teknologi Masyarakat, perangkat pembelajaran untuk model pembelajaran direct instruction dan tes hasil belajar fisika. Analisis data tes dilakukan dengan teknik statistik uji-t dua pihak untuk melihat adanya perbedaan pada kedua kelas yang menggunakan model pembelajaran sains teknologi masyarakat dan yang menggunakan model pembelajaran direct instruction. Berdasarkan hasil pengolahan data penelitian, diperoleh hasil pengujian hipotesis dengan taraf nyata $\alpha=0,05$ berdasarkan tes akhir dengan menggunakan skor rata-rata maka diperoleh $t_{\text {hitung }}=8,04$ dan $t_{\text {tabel }}=1,98$, maka $H_{0}$ ditolak dan hipoteis satu $\left(H_{1}\right)$ diterima artinya terdapat perbedaan hasil belajar antara kelas eksperimen dan kelas kontrol.
\end{abstract}

Kata Kunci: model pembelajaran sains teknologi masyarakat; model pembelajaran Direct Instruction; dan hasil belajar

\section{PENDAHULUAN}

Kebanyakan orang menganggap bahwa belajar merupakan kegiatan yang tidak menarik dan membosankan. Padahal belajar akan membuka jendela pemahaman manusia terhadap hakikat segala sesuatu. Dengan belajar, manusia akan dapat memahami hakikat diri, lingkungannya, dan hakikat pencipta diri dan lingkungannya.

Pembelajaran IPA pada umumnya adalah suatu tempat bagi siswa untuk mengenali dirinya sendiri dan juga alam sekitarnya. Misalnya fisika yang merupakan salah satu pelajaran penting karena didalamnya terdapat keterkaitan dengan kehidupan di masyarakat. Seharusnya pembelajaran fisika bisa lebih erat kaitanya dengan kehidupan sehari-hari, sehingga konsep-konsep yang ada dalam fisika bisa diaplikasikan dengan mudah oleh siswa.

Berdasarkan hal ini, maka sudah seharusnya fisika dipelajari secara menyenangkan, karena mempelajari fisika berkaitan dengan kehidupan manusia yang menggantungkan hidupnya kepada alam. Fisika ditemukan dan dikembangkan berdasarkan masalah-masalah yang dihadapi manusia terkait dengan kehidupannya. Oleh karena itu tampak bahwa sebetulnya fisika dianjurkan untuk dipelajari oleh setiap orang. Namun fakta yang ada di masyarakat adalah sebaliknya. Setidaknya terdapat anggapan bahwa fisika termasuk kelompok mata pelajaran yang sulit dan membosankan. Pelajaran fisika cenderung dianggap sulit dan membosankan oleh sebagian 
siswa. Bahkan anggapan ini hampir dimiliki oleh semua orang.

Mempelajari fisika, sebetulnya dapat lebih mengenal alam sekitar. Permasalahan yang muncul adalah siswa hanya mengetahui dan menghafal konsep fisika yang diajarkan, tetapi mereka kurang memahami konsep tersebut. Sebagian besar siswa tidak mampu menghubungkan apa yang mereka pelajari dengan kehidupan sehari-hari.

Novrizal menyatakan bahwa siswa yang diajarkan dengan model pembelajaran sains teknologi masyarakat memiliki penguasaan konsepnya lebih tinggi. Hal ini disebabkan siswa yang diajar dengan model pembelajaran sains teknologi masyarakat mempunyai kesempatan untuk lebih aktif dalam mengikuti kegiatan belajar mengajar. Model pembelajaran sains teknologi masyarakat juga melatih siswa untuk memadukan antara konsep yang telah diperoleh dari penjelasan guru di kelas dengan konsep yang didapat oleh mereka sendiri baik dari bukubuku maupun internet. Dalam hal ini, siswa diajarkan untuk dapat bekerja sama secara berkelompok dalam menyelesaikan berbagai masalah dan membuat alternatif untuk mengatasi permasalahan yang dihadirkan oleh guru mengenai materi yang dikaji. Pembelajaran fisika yang diawali dengan isu atau masalah aktual yang ada di masyarakat kemudian dikaitkan dengan teknologi yang telah berkembang, maka konsep-konsep yang telah dipelajari dan dikuasai siswa diharapkan dapat bermanfaat bagi dirinya dan dapat digunakan untuk menyelesaikan masalah yang dihadapinya di lingkungan sosialnya [1].

Reynold dan Farell pada tahun 1996 melakukan sebuah penelitian. Penelitian ini merupakan penelitian komparasi bertaraf internasional. Salah satu contohnya adalah yang berjudul World Apart Report. Laporan ini menjelaskan perbandingan metode yang digunakan di Inggris dan Singapura. Para penulis laporan ini menemukan fakta bahwa salah satu faktor yang meyebabkan perbedaan hasil belajar siswa di kedua negara itu adalah penggunaan pengajaran interaktif whole-class yang merupakan salah satu faktor utama pembelajaran direct instruction [2].

Berdasarkan uraian di atas, maka diasumsikan bahwa kedua pembelajaran ini dapat meningkatkan hasil belajar dan menjadikan pembelajaran berlangsung menyenangkan. Oleh karena itu, pada penelitian ini akan dilakukan sebuah eksperimen yang mencoba memberikan sebuah solusi bagi permasalahan di atas dengan cara menerapkan model pembelajaran sains teknologi masyarakat dan direct instruction, dengan demikian diharapkan dapat meningkatkan hasil belajar dan mengubah persepsi siswa terhadap pelajaran fisika menjadi lebih positif.

Pada penelitian ini akan diterapkan dua jenis model pembelajaran, yaitu model pembelajaran sains teknologi masyarakat dan model pembelajaran direct instruction. Kedua model pembelajaran ini dianggap akan mampu memberikan solusi terhadap permasalahan sebagaimana diuraikan pada penjelasan di atas. $\mathrm{Hal}$ itu dikarenakan kedua model pembelajaran tersebut merupakan model pembelajaran yang lebih bermakna sehingga dapat membekali siswa dalam menghadapi permasalahan hidup yang akan mereka hadapi dalam kehidupannya.

Berdasarkan uraian di atas, peneliti bermaksud untuk melakukan penelitian yang bertujuan 
untuk melihat perbedaan hasil belajar fisika antara model pembelajaran sains teknologi masyarakat dan model pembelajaran direct instruction pada siswa kelas X SMA Negeri 1 Palu.

\section{METODOLOGI}

Penelitian ini merupakan penelitian eksperimen kuasi dengan mengambil dua kelas secara purposive pada sekolah SMA Negeri 1 Palu. Kedua kelas ini yaitu kelas $\mathrm{X}-6$ sebagai kelas eksperimen yang diterapkan model pembelajaran sains teknologi masyarakat dengan jumlah siswa 44 orang dan kelas X-8 sebagai kelas kontrol yang diterapkan model pembelajaran direct instruction dengan jumlah siswa sebanyak 44 orang. Ruang lingkup dalam penelitian ini hanya mencakup pada hasil belajar fisika siswa.

Data dalam penelitian ini diperoleh dari tes hasil belajar fisika yang diberikan pada awal dan akhir pembelajaran. Adapun desain penelitian yang digunakan dalam penelitian ini adalah sebagai berikut:

Tabel 1 Desain Penelitian : The Non

Ekivalen Pretest-Postest Design

\begin{tabular}{|l|c|c|c|}
\hline \multicolumn{1}{|c|}{ Group } & $\begin{array}{c}\text { Tes } \\
\text { Awal }\end{array}$ & Perlakuan & $\begin{array}{l}\text { Tes } \\
\text { Akhir }\end{array}$ \\
\hline $\begin{array}{l}\text { Kelas } \\
\text { eksperimen }\end{array}$ & 0 & $X$ & 0 \\
\hline $\begin{array}{l}\text { Kelas } \\
\text { kontrol }\end{array}$ & 0 & - & 0 \\
\hline
\end{tabular}

III. HASIL DAN PEMBAHASAN
Hasil dari tes hasil belajar fisika yang diberikan pada kelas eksperimen dan kelas kontrol disajikan pada Tabel 2.

Tabel 2 Skor Tes Hasil Belajar Fisika Pada Kelas Eksperimen Dan Kelas Kontrol.

\begin{tabular}{|c|c|c|c|c|}
\hline \multirow{2}{*}{ Uraian } & \multicolumn{2}{|c|}{ Tes Awal } & \multicolumn{2}{c|}{ Tes Akhir } \\
\cline { 2 - 5 } & $\begin{array}{c}\text { Kelas } \\
\text { Eksperi } \\
\text { men }\end{array}$ & $\begin{array}{c}\text { Kelas } \\
\text { Kontr } \\
\text { ol }\end{array}$ & $\begin{array}{c}\text { Kelas } \\
\text { Eksperi } \\
\text { men }\end{array}$ & $\begin{array}{c}\text { Kelas } \\
\text { Kontrol }\end{array}$ \\
\hline Sampel & 44 & 44 & 44 & 44 \\
\hline $\begin{array}{c}\text { Skor } \\
\text { Terend } \\
\text { ah }\end{array}$ & 0 & 0 & 14 & 7 \\
\hline $\begin{array}{c}\text { Skor } \\
\text { Terting } \\
\text { gi }\end{array}$ & 14 & 14 & 24 & 22 \\
\hline $\begin{array}{c}\text { Skor } \\
\text { Rata- } \\
\text { rata }\end{array}$ & 8,05 & 9,02 & 20,41 & 15,91 \\
\hline $\begin{array}{c}\text { Skor } \\
\text { Ideal }\end{array}$ & 30 & 30 & 30 & 30 \\
\hline $\begin{array}{c}\text { Persent } \\
\text { ase }\end{array}$ & 26,83 & 30,07 & 68,03 & 53,03 \\
\hline
\end{tabular}

Adapun persentase perolehan skor rata-rata hasil belajar fisika pada siswa baik tes awal maupun tes akhir dapat dilihat pada Gambar 1. 


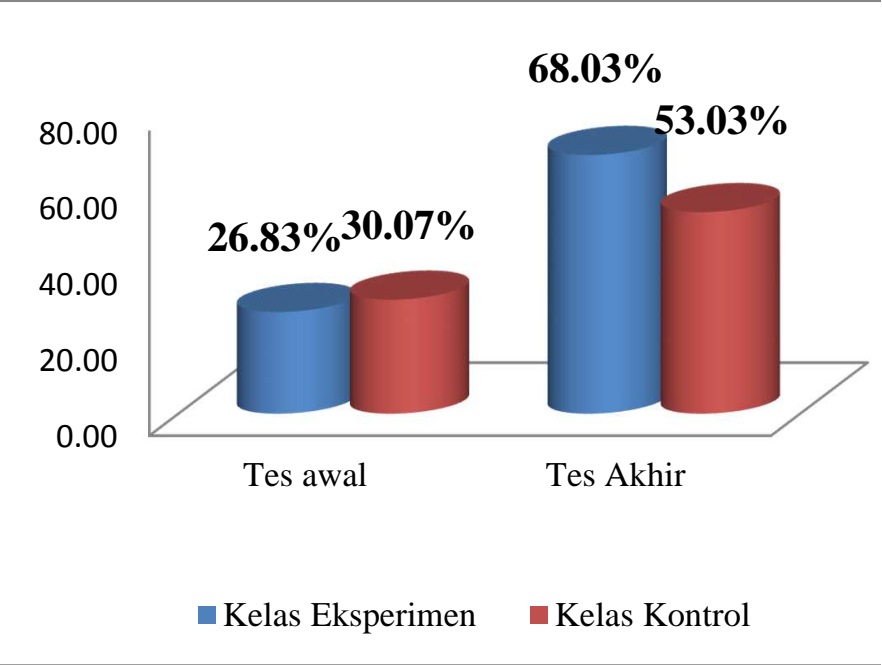

Gambar 1 Deskripsi Persentase Skor RataRata Hasil Belajar Fisika Pada Tes Awal Dan Tes Akhir

Hasil yang diperoleh dari uji hipotesis data hasil belajar fisika antara kelas eksperimen dan kelas kontrol ditunjukkan pada Tabel 3.

Tabel 3 Uji-t Data Tes Antara Kelas Eksperimen Dan Kelas Kontrol

\begin{tabular}{|c|c|c|c|c|}
\hline \multirow{2}{*}{ Uraian } & \multicolumn{2}{|c|}{ Tes Awal } & \multicolumn{2}{c|}{ Tes Akhir } \\
\cline { 2 - 5 } & $\begin{array}{c}\text { Kelas } \\
\text { Eksperi } \\
\text { men }\end{array}$ & $\begin{array}{c}\text { Kelas } \\
\text { Kontrol }\end{array}$ & $\begin{array}{c}\text { Kelas } \\
\text { Ekspe } \\
\text { rimen }\end{array}$ & $\begin{array}{c}\text { Kelas } \\
\text { Kontrol }\end{array}$ \\
\hline Sampel & 44 & 44 & 44 & 44 \\
\hline $\mathrm{dk}$ & \multicolumn{2}{|c|}{86} & \multicolumn{2}{c|}{86} \\
\hline$t_{\text {hitung }}$ & \multicolumn{2}{|c|}{1,27} & \multicolumn{2}{c|}{8,04} \\
\hline$t_{\text {tabel }}$ & \multicolumn{2}{|c|}{1,98} & \multicolumn{2}{c|}{1,98} \\
\hline$H_{0}$ & \multicolumn{2}{|c|}{ diterima } & \multicolumn{2}{c|}{ Ditolak } \\
\hline
\end{tabular}

Pengujian hipotesis yang dilakukan pada taraf signifikan $(\alpha=0,05)$ dan $\mathrm{dk}=(44+44)-2=86$ dengan kriteria pengujian yakni, diterimanya $H_{0}$ jika $-t_{(1-0,5 \alpha)}<t<t_{(1-0,5 \alpha)}$. Maka untuk pengujian hipotesis berdasarkan tes awal dengan menggunakan rata-rata skor diperoleh $t_{\text {hitung }}=1,27$ dan $t_{\text {tabel }}=1,98$, maka kriteria penerimaan $H_{0}$ dimana $-1,98<1,27<1,98$ terpenuhi, $H_{0}$ diterima dan hipoteis satu $\left(H_{1}\right)$ ditolak artinya tidak terdapat perbedaan hasil belajar fisika antara kelas eksperimen dan kelas kontrol. Untuk pengujian hipotesis berdasarkan tes akhir dengan menggunakan skor rata-rata maka diperoleh $t_{\text {hitung }}=8,04$ dan $t_{\text {tabel }}=1,98$, maka kriteria penerimaan $H_{0}$ dimana $-t_{(1-0,5 \alpha)}<$ $t<t_{(1-0,5 \alpha)}$ tidak terpenuhi, $H_{0}$ ditolak dan hipoteis satu $\left(H_{1}\right)$ diterima artinya terdapat perbedaan hasil belajar fisika antara kelas eksperimen dan kelas kontrol.

Penelitian ini bertujuan untuk mengetahui perbedaan hasil belajar fisika antara model pembelajaran sains teknologi masyarakat dan model pembelajaran direct instruction. Pada kelas eksperimen diterapkan model pembelajaran sains teknologi masyarakat sedangkan pada kelas kontrol diterapkan model pembelajaran direct instruction. Model pembelajaran sains teknologi masyarakat merupakan cara belajar siswa untuk mengaitkan antara sains yang mereka dapatkan kemudian menerapkan pada teknogi di masyarakat. Masyarakat pada umumnya merupakan masyarakat modern yaitu masyarakat yang selalu mengikuti perubahan zaman. Oleh karena itu peneliti lebih banyak mengaitkan sains dengan lingkungan masyarakat modern. Sedangkan pada model pembelajaran direct instruction cocok digunakan pada pokok bahasan materi yang tidak abstrak. Selain itu pada model pembelajaran direct instruction guru lebih mudah mengalokasikan waktu dalam pembelajaran di kelas.

Bentuk tes yang digunakan pada penelitian ini adalah tes pilihan ganda berjumlah 30 nomor. Tes tersebut digunakan untuk mengukur hasil belajar fisika pada siswa. Tes dilakukan sebelum 
dan sesudah pembelajaran berlangsung. Setelah melakukan tes awal baik pada kelas eksperimen maupun pada kelas kontrol maka pada masingmasing kelas memperoleh rerata skor yaitu pada kelas eksperimen 8,05 dan kelas kontrol 9,02. Dari nilai yang diperoleh tersebut, kemudian dilakukan uji normalitas dan uji homogenitas yang dimaksudkan untuk melihat kondisi awal hasil belajar fisika dari kedua kelas tersebut. Hasil dari kedua uji tersebut menyatakan bahwa tidak ada perbedaan yang signifikan antara kelas eksperimen dan kelas kontrol. Hal ini dapat dilihat setelah dilakukan uji parametrik dua pihak yang menyatakan bahwa kedua kelas tersebut merupakan sampel yang berasal dari kelas yang homogen. Untuk itu dapat dikatakan bahwa kedua kelas memiliki kemampuan awal yang sama.

Analisis data tes akhir yang digunakan untuk melihat perbedaan hasil belajar fisika antara model pembelajaran sains teknologi masyarakat dengan model pembelajaran direct instruction adalah uji hipotesis dua pihak. Uji hipotesis dua pihak dapat dilakukan jika data tersebut terdistribusi normal dan kedua sampel memiliki varians yang sama. Nilai $t_{\text {hitung }}$ sebesar 8,04 dan nilai $t_{\text {tabel }}$ pada taraf signifikansi $(\alpha=0,05)$ sebesar 1,98. Berdasarkan uji hipotesis yang dilakukan diperoleh bahwa $t_{\text {hitung }}$ pada daerah penerimaan $H_{1}$ sehingga $H_{0}$ ditolak dan $H_{1}$ diterima. Hal ini menunjukkan bahwa terdapat perbedaan hasil belajar antara model pembelajaran sains teknologi masyarakat dan model pembelajaraan direct instruction pada siswa kelas X SMA Negeri 1 Palu.

Model pembelajaran sains teknologi masyarakat memiliki tahapan pembelajaran yang dapat meningkatan pemahaman siswa terhadap materi yang disampaikan. Hal ini disebabkan dengan menerapkan model pembelajaran sains teknologi masyarakat siswa lebih antusias menyimak materi yang disampaikan. Pada tahap awal guru menghadirkan isu-isu atau masalah yang sering mereka lakukan sehingga akan menimbulkan pro dan kontra pada siswa. Misalnya pada materi gerak, peneliti memberikan pertanyaan kepada siswa "siapa yang pernah naik pete-pete yang melaju dengan kencang di jalan lurus?" Kemudian siswa menjawab bersamaan dengan mengacungkan tangan menandakan bahwa mereka pernah merasakannya. Kembali peneliti bertanya "kalian perhatikan keadaan sekitar kayak pohon ataupun tanaman lainnya? Apakah pohon-pohon itu seperti bergerak? Bagaimanakah kalian menanggapi gerakan pohon tersebut yang semakin lama semakin menjauhi kamu?"Disinilah siswa mengeluarkan berbagai pendapat seperti yang mereka alami, kemudian muncul pendapat yang pro dan kontra. Kemudian peneliti menjelaskan tentang materi gerak lurus. Pada tahap ini peneliti menanamkan konsep yang berkaitan dengan materi yang sedang diajarkan. Setelah siswa paham dengan materi tersebut, maka beranjak pada tahap berikutnya yaitu tahap aplikasi. Pada tahap ini siswa dituntut untuk mampu menerapkan konsep dari materi tersebut dalam melakukan percobaan. Percobaan yang dilakukan pada tahap aplikasi ini hanya berlangsung pada pertemuan 2, 3 dan 4 . Sedangkan pada pertemuan 1 siswa hanya dihadapkan pada soal sains teknologi masyarakat yang merujuk pada tes hasil belajar. Hal ini disebabkan materi pada pertemuan 1 merupakan materi dasar yang berisi mengenai 
perpindahan, jarak, kecepatan dan percepatan saja. Setelah tahap aplikasi, peneliti menekankan kembali konsep-konsep gerak lurus agar tidak terjadi miskonsepsi. Pada tahap ini, peneliti dan siswa melakukan tanya jawab tentang hal-hal yang kurang dipahami oleh siswa. Setelah tidak ada miskonsepsi maka diberikan soal berkaitan dengan materi yang telah disampaikan sebagai tahap evaluasi. Tahap evaluasi digunakan sebagai penilaian pemahaman siswa terhadap materi yang telah dipelajari.

Model pembelajaran sains teknologi masyarakat melatih siswa untuk selalu aktif dalam menyelesaikan masalah terutama pada tahap aplikasi. Sehingga siswa berlatih mengeluarkan ide-ide mereka berdasarkan pengalaman dan pengetahuan mereka. Selain itu siswa juga dituntut aktif dalam mengungkapkan isu-isu yang ada di lingkungan maupun yang pernah mereka alami. Pembelajaran STM adalah merupakan perekat yang mempersatukan sains, teknologi dan masyarakat. Ciri-ciri model pembelajaran STM antara lain: difokuskan pada isu-isu sosial dan teknologi di masyarakat dan lingkungan yang terkait dengan konsep atau prinsip sains yang akan dikaji. Novrizal (2010) juga menegaskan bahwa siswa yang diajarkan dengan model pembelajaran sains teknologi masyarakat mempunyai kesempatan lebih aktif dalam mengikuti kegiatan belajar mengajar. Model pembelajaran sains teknologi masyarakat juga melatih siswa untuk memadukan antara konsep yang telah diperoleh dari penjelasan guru di kelas dengan konsep yang didapat oleh mereka sendiri baik dari buku maupun internet [3].
ISSN 9772338324004

Model pembelajaran sains teknologi masyarakat memudahkan siswa memahami materi karena siswa diajak untuk mengaitkan antara sains yang sedang dikaji dengan teknologi di masyarakat. Selain itu siswa juga diajak untuk mengaplikasikan dalam praktikum sehingga dengan siswa mendapatkan kesempatan untuk bereksperimen dan menyelesaikan masalah dengan menerapkan konsep yang telah diperoleh sebelumnya. Sehingga dengan melakukan eksperimen maka siswa dapat mengalami sendiri dan membekas dalam ingatan mereka. Dengan demikianmodel pembelajaran sains teknologi masyarakat dapat meningkatkan hasil belajar fisika siswa.

Model pembelajaran sains teknologi masyarakat yang diterapkan menemui kendala saat proses pembelajaran berlangsung. Bagi peneliti beberapa kendala tersebut adalah sulitnya mengalokasikan waktu dengan tepat, karena model pembelajaran sains teknologi ini memiliki tahapan yang cukup banyak. Hal ini disebabkan peneliti belum optimal dalam menguasai kelas. Poedjiadi menyatakan bahwa pembelajaran yang menggunakan model pembelajaran sains teknologi masyarakat apabila dirancang dengan baik, memakan waktu lebih lama bila dibandingkan dengan modelmodel lain. Hal ini disebabkan karena bagi guru tidak mudah untuk mencari isu atau masalah pada tahap pendahuluan yang terkait dengan topik yang dibahas atau dikaji, karena hal ini memerlukan adanya wawasan luas dari guru dan melatih tanggap terhadap masalah lingkungan [4].

Model Pembelajaran direct instruction yang diterapkan di kelas kontrol ini juga mempunyai kelebihan tentang pengalokasian waktu dalam 
setiap tahapnya itu bisa disesuaikan dan pemberian tugas-tugas bisa secara maksimal. Kardi,S \& Nur menyatakan bahwa ada dua hal yang menonjol terkait dengan hasil pelaksanaan model pembelajaran direct intruction, yaitu: alokasi waktu dan penggunaan tugas (kegiatan) yang menggunakan model pembelajaran direct instruction lebih berhasil dan mencapai tingkat keterlibatan yang tinggi daripada metodemetode informal yang berpusat pada siswa [5].

Pembelajaran direct instruction memiliki beberapa kendala yaitu guru lebih mendominasi daripada siswa sehingga siswa menjadi pasif dan cenderung susah menyelesaikan permasalahan dalam proses pembelajaran. Pembelajaran lebih bersifat teoritis dan abstrak, karena siswa tidak mengalaminya sendiri. Selain itu, siswa yang diajar dengan menggunakan model pembelajaran direct instruction kurang memiliki kesempatan untuk mengasah kemampuan dalam menyelesaikan masalah. Jadi inilah yang merupakan faktor penyebab dari lebih kecilnya nilai rata-rata tes akhir pada kelas kontrol.

\section{KESIMPULAN}

Berdasarkan penelitian dan analisis data penelitian, maka dapat disimpulkan bahwa terdapat perbedaan hasil belajar fisika antara model pembelajaran sains teknologi masyarakat dan model pembelajaran direct intruction. Hal ini dapat diketahui melalui hasil pengujian hipotesis dengan menggunakan uji-t dua pihak dimana $t_{\text {hitung }}=8,04$ dan $t_{\text {tabel }}=1,98$, maka $H_{0}$ ditolak dan hipoteis satu $\left(H_{1}\right)$ diterima artinya terdapat perbedaan hasil belajar antara kelas eksperimen dan kelas kontrol.

\section{DAFTAR PUSTAKA}

ISSN 9772338324004

[1] Novrizal, Ferdi. (2010). Pengaruh Model Pembelajaran Sains teknologi Masyarakat Terhadap Peningkatan Penguasaan Konsep Usaha Dan Energi. Jakarta: Universitas Islam Negeri Syarif Hidayatullah.

[2] Nuruddin, Moh. (2010). Perbandingan Hasil Belajar Fisika Antara Siswa Yang Menggunakan Problem Based Learning Dengan Direct Instruction. Jakarta: Universitas Islam Negeri Syarif Hidayatullah.

[3] Yulianti, dkk.(2012). Pengaruh Model Pembelajaran Sains Teknologi Masyarakat Berbantuan Media Audio Visual Terhadap Prestasi Belajar Ipa Sd Gugus I Banyuning. Singaraja: Universitas Ganesa.

[4] Poedjiadi, Anna. (2010). Sains Teknologi Masyarakat. Bandung: PT. Remaja Rosdakarya.

[5] Kardi, S, \& Nur, M. (2000). Pengajaran Langsung.Surabaya: UNESA - University Press. 